\title{
UMA LEITURA DO FUTEBOL EM SÃO PAULO: A GINGA, OS TERRITÓRIOS E AS IDENTIDADES
}

\author{
Marco BetTine Almeida \\ Universidade de São Paulo / Brasil \\ marcobettine@,usp.br \\ GUSTAVO GUTIERREZ \\ Universidade Estadual de Campinas / Brasil \\ glgutierrez@,terra.com.br \\ RENATO MARQUES \\ Universidade de São Paulo / Brasil \\ renatomarques@usp.br
}

\begin{abstract}
Resumo
Neste ensaio buscamos discutir alguns aspectos do futebol, a partir de um olhar sistêmico da sociedade. Faremos uma breve passagem pelos autores ligados às ciências sociais que interpretaram a relação orgânica entre futebol, nação e brasilidade. Para isso, discutiremos a questão do corpo, da ginga e da reinterpretação cultural de um jogo praticado por ingleses em São Paulo, para uma ressignificação brasileira de como jogar e valorizar o futebol como um patrimônio nacional. Abordaremos, também, os territórios e as identidades do futebol no Estado de São Paulo, como foram constituídos espaços e a transformação dos mesmos, de um jogo praticado às margens do Rio Tietê, até a construção do monumento do Estádio Municipal do Pacaembu.
\end{abstract}

Palavras-chave: Futebol; São Paulo; Sociologia do Esporte.

\section{Una lectura del fútbol en São Paulo: la ginga, territorios e identidades}

\section{Resumen}

En este ensayo se discuten algunos aspectos del fútbol, desde una perspectiva sistémica de la sociedad. Vamos a informar los autores vinculados a las ciencias sociales, que interpretan la relación orgánica entre la nación de fútbol y brasilidad. Para esto, vamos a discutir el tema del cuerpo, la ginga y la reinterpretación cultural de un juego jugado por los ingleses en Sao Paulo, Brasil, para una redefinición brasileña sobre cómo jugar y apreciar el fútbol como un bien nacional. También vamos a discutir los territorios e identidades del fútbol en el estado de São Paulo, cómo se constituyeron los espacios y la transformación de estos espacios, de un juego jugado en las orillas del Tietê, hasta la construcción del monumento del estadio municipal Pacaembu.

Palabras clave: Fútbol; São Paulo; Sociología del Deporte.

A reading of football in São Paulo: the ginga, territories and identities

\begin{abstract}
In this essay we discuss some aspects of football, from a systemic perspective of society. We briefly present the authors linked to the social sciences who interpreted the organic relationship among football, nation and Brazilianness. For this, we will discuss the issues of body, ginga (swing) and cultural reinterpretation of a game played by Englishmen in Sao Paulo, to a redefinition how to play
\end{abstract}


and appreciate football as a national asset. We also discuss the territories and identities of football in the state of São Paulo, how spaces were constituted and transformed, and a match played on the banks of Tietê river, until the construction of the monument of the Pacaembu municipal stadium.

Key-words: Football; São Paulo; Sociology of Sport.

\section{Introdução}

O futebol é um fenômeno sociocultural que representa a principal manifestação esportiva no Brasil. Compreender como ele participa da nossa configuração cultural se faz pertinente como forma de melhor descrever a sociedade brasileira, visto que é um dos poucos fenômenos sociais que sintetiza a nacionalidade de grande abrangência territorial e diversidade cultural.

Este ensaio teve como objetivo trazer ao debate várias faces do processo de apropriação do futebol no Estado de São Paulo. Para tal, algumas características foram incorporadas como ferramentas de análise deste fenômeno: (a) a relação orgânica entre futebol, nação e brasilidade, expressas pela reinterpretação cultural deste esporte pelo povo brasileiro; (b) a ressignificação brasileira de como jogar e valorizar o futebol como um patrimônio nacional; e (c) os territórios e as identidades do futebol no Estado de São Paulo.

Para isso, foram utilizados autores das ciências sociais que possibilitem uma sustentação teórica para a caracterização do futebol como um objeto incorporado à cultura brasileira de forma ressignificada. Ou seja, com traços culturais próprios do povo brasileiro, mas com a estrutura objetiva específica da prática criada na Inglaterra.

\section{O Futebol em São Paulo: uma discussão dos territórios e das identidades}

São muitos os escritos sobre o papel de Charles Miller na difusão do futebol em São Paulo. Dentre estas discussões destaca-se o texto de Rosenfeld (1973: 62). Para o autor:

... o futebol foi transplantado para o Brasil por Charles Miller, um brasileiro de origem Inglesa. Aos dez anos de idade foi enviado pelos pais à terra de seus pais para frequentar a escola. Quando voltou a São Paulo, em 1894, trouxe em sua mala uma bola de futebol. Para difundir entre os ingleses, que viviam em São Paulo e jogavam cricket, Miller entregou-se a uma fervorosa atividade de missionário. O primeiro círculo que cultivou o jogo de uma forma organizada foi formado por sócios de um clube inglês - o São Paulo Athletic Club, que havia sido fundado para a prática do cricket e ao qual Miller se associou. O clube reunia altos funcionários ingleses da Cia. de Gás, do Banco de Londres e da São Paulo Railway.

A maior parte dos pesquisadores que se interessaram em escrever sobre as origens do futebol em São Paulo acabou concordando em datar a chegada da prática futebolística com a volta do brasileiro 
Charles Miller, que havia ido estudar na Inglaterra. Na ocasião, trouxe alguns equipamentos básicos para praticar o futebol, introduzindo esse esporte no país. Essa é a versão mais aceita, como sugere Mills (2005), que defende que as práticas ocorridas nos colégios jesuítas e nos portos não eram exatamente futebol, pois não respeitavam as regras formalizadas e institucionalizadas da modalidade. Segundo o autor, quem apresentou tal configuração no Brasil foi mesmo Charles Miller.

Jogos com bola já haviam sido praticados anteriormente, pelo menos 20 anos antes. Fala-se de uma escola dirigida por padres jesuítas no interior de São Paulo, mais precisamente em Itu, assim como por marinheiros ingleses, próximos a um porto brasileiro (Mills, 2005).

Ninguém duvida que nos colégios jesuíticos possa ter havido jogos de bola com os pés, como aqueles disputados nos colégios ingleses de Eton e Harrow na hora do recreio. Porém, não eram jogos organizados, que seguiam as regras da Association Football. Marinheiros Britânicos também foram vistos com bolas de futebol nas praias de portos brasileiros em que atracavam, jogando suas peladas na areia, totalmente alheios à gente em volta (Mills, 2005: 78).

Deste modo, pode-se apontar que o futebol moderno surgiu na Inglaterra e tem em São Paulo seu primeiro espaço de disputa no Brasil, dirigida por entidades organizadas com esse fim. O início efetivo do esporte moderno ocorreu após a Revolução Industrial (Dunning \& Curry, 2006). O maior tempo livre resultante da legislação, no início do século XIX, dirigiu-se para uma série de outras atividades, que favoreceram o início do esporte (Elias \& Dunning, 1992). A Inglaterra estabeleceu a folga aos sábados e domingos (a chamada "semana inglesa"), o que propiciou e favoreceu a utilização do tempo livre para a prática esportiva.

Foi principalmente no meio universitário britânico que o esporte começou a ser praticado. Jovens das principais escolas inglesas foram os pioneiros a se dedicar a várias modalidades que, com o passar do tempo, foram consolidadas como olímpicas e transformaram o esporte em valor cultural. Após regressar dessas universidades, estes jovens tornaram-se agentes de difusão da atividade esportiva pelo mundo, missão profissional, deixando parte deste valor cultural em todas as regiões em que se radicavam de forma temporária ou permanente (Dunning \& Curry, 2006).

Da mesma forma que Miller, Oscar Cox, após terminar seus estudos na Suíça, retornou ao Brasil e tornou-se o difusor do futebol no Rio de Janeiro e o primeiro presidente do Fluminense. O introdutor do futebol em Salvador foi José Zuza Ferreira, que levou à capital baiana a primeira bola em 1901 ao voltar da Inglaterra. Em 1904, Vitor Serpa criou o Sport Club em Minas Gerais, e em 1905, Guilherme de Aquino Fonseca começou a difundir o futebol em Pernambuco, após concluir seus estudos, também na Inglaterra (Nogueira, 2006). 
Não é objetivo discutir quando ocorreu o primeiro jogo, nem mesmo se os sujeitos acima relatados são os primeiros a trazer bolas e materiais. Na história é mais intrigante conhecer seus contornos do que sistematizar um nome, um fim, como se a partir deste relato decretássemos o fim da história. Neste sentido, os nomes trazidos têm a ideia de apresentar o seguinte contexto: há uma percepção que jovens da elite europeia, principalmente inglesa, de pais radicados no Brasil, entraram em contato com o futebol sistematizado e burocratizado, trazendo esta nova prática à luz dos documentos oficiais. Este fato não impede perceber que marinheiros ingleses, entre outros, poderiam já praticar o futebol de forma não sistematizada, porém distante dos holofotes de jornalistas e de pessoas que escreveram o cotidiano do fim do século XIX e começo do XX.

O início da prática esportiva no país não contou com as classes menos abastadas, seguindo a tendência da elitização, porém sua introdução acompanha uma série de condições sociais prévias do esporte, como a libertação dos escravos, a Proclamação da República e o rápido desenvolvimento das cidades, especialmente São Paulo. Esta elitização não impediu que o futebol ganhasse a aceitação popular num período de vinte anos (1894-1914), propiciando a consolidação do futebol como esporte de massas.

O primeiro clube a jogar futebol foi o São Paulo Athletic Club. Este clube tinha como sócios diretores da São Paulo Railway e outros membros da colônia inglesa, eles se encontravam, anteriormente, para jogar cricket numa várzea, nas proximidades da Ponte Grande (uma das pontes que atravessam o Rio Tietê, que dividia a capital paulista). Posteriormente, a Associação Atlética Mackenzie College de São Paulo, liderada por Augusto Shaw, professor do Mackenzie College, também passou a se dedicar à modalidade, dando origem ao Mackenzie como clube de futebol. No final do século XIX e começo do século XX outros clubes foram fundados no Estado de São Paulo, que não se iniciaram pelo futebol, mas que logo começaram a se dedicar exclusivamente a ele, como é o caso do S. C. Savoia de Sorocaba, a Associação Atlética Ponte Preta de Campinas e o Clube Atlético Paulistano de São Paulo.

Em 1902 ocorreu o primeiro campeonato paulista, contando com a participação do São Paulo Athletic Club, o S. C. Germânia, o S. C. Internacional, o C. A. Paulistano e o Mackenzie College. Por no mínimo quinze anos, o futebol foi dominado pelos clubes mais ricos apesar de já existirem os clubes chamados varzeanos. Neste sentido, as fronteiras sociais do futebol começaram a ser transpostas através da formação de times improvisados pelos setores populares e, o que antes era simples curiosidade destas camadas, passou a ser prática oficial. Como hoje assistimos crianças jogando futebol com pedras, bola de meias, ontem não era diferente: o futebol era praticado com materiais improvisados, jogado em terrenos desocupados, tornando-se uma representação da existência negada em outros campos sociais, alastrando-se pelos subúrbios. Logo, as equipes e clubes foram se constituindo pela iniciativa de 
pequenos comerciantes, operários e artesãos, como o Internacional em 1909 e o Sport Club Corinthians Paulista em 1910 (Franco Jr., 2007).

O amadorismo oferecia gratificações aos jogadores. Os atletas, que se sobressaíam, recebiam privilégios e, por isso, passavam a se dedicar mais ao clube do que propriamente à empresa da qual eram contratados. Quando eram realizados amistosos e campeonatos, os clubes de elite costumavam cobrar elevados valores pelos ingressos e mensalidades de seus sócios, enquanto que os clubes populares preocupavam-se em oferecer condições mais acessíveis para seus associados nos torneios e confrontos que organizavam. Nesta época, o futebol desenvolveu um enorme potencial econômico, uma vez que o "amadorismo marrom", praticado desde 1910, sustentava-se das bilheterias e dos ricos patronos dos clubes. $\mathrm{O}$ amadorismo só foi se desconstituir anos depois, com a transição política do governo, que em 1933 reconheceu o jogador de futebol como profissional regulamentado pela legislação trabalhista.

Giullianotti (2010), em suas pesquisas sobre o processo de disseminação do futebol pelo mundo, trouxe algumas considerações importantes mostrando que o processo de difusão deu-se com semelhanças ao processo brasileiro. Segundo o autor, os primeiros clubes fora da Inglaterra foram estabelecidos na Suíça pelos rapazes ingleses que frequentavam escolas particulares. $\mathrm{Na}$ Escandinávia, o jogo contrabalançou com os ginastas nórdicos, surgindo primeiro na Dinamarca em 1879. Os artesãos escoceses levaram o jogo para Suécia no final do século XIX, enquanto as conexões britânicas levaram o futebol para os noruegueses no início da década de 1880. Trabalhadores do algodão, de Lancashire, foram considerados os primeiros expoentes na Holanda em meados do século XIX, inspirando a formação na primeira Associação de Futebol não inglesa em 1889. As escolas inglesas foram centrais para a popularização do futebol na Alemanha e na Rússia. O futebol espanhol desenvolveu-se após ter aterrissado no País Basco com os trabalhadores marítimos e os carvoeiros da Grã-Bretanha, que o jogavam durante a década de 1890. Na Itália, marinheiros ingleses e os negociantes introduziram o jogo moderno em Gênova, Milão, Turim e Nápoles. Na França, durante a Belle Epóque, os primeiro times de futebol foram formados pelos escoceses e ingleses exilados em Paris.

$\mathrm{Na}$ América Latina as relações comerciais mostraram-se o canal mais fértil para a colonização do futebol. A primeira experiência no Brasil chegou com os marinheiros ingleses em 1864, mas foi Charles Miller, de São Paulo, educado na Grã-Bretanha, que se tornou o mais ardente proponente do jogo. O futebol também chegou ao rio de La Plata quando 45 mil cidadãos da Grã-Bretanha, que moravam em Buenos Aires, começaram a criar Clubes, particularmente via escolas britânicas. A influência Inglesa continuou por meio da fundação e denominação de clubes por ex-alunos e trabalhadores ferroviários tais como, na capital, o River Plate, ou os dois em Rosário Newell's Old Boys (fundado pelos primeiros alunos de um professor inglês) e o Rosário Central (depois da estação ferroviária local). O primeiro clube voltado para o futebol uruguaio, Albion FC, foi fundado em junho de 1861, em Montevidéu. Duas 
décadas depois, havia notícias de que o futebol era jogado nas aulas de educação física nas escolas secundárias. Os trabalhadores ferroviários ingleses fundaram, em 1891, o que se tornou o clube Peñarol. Seu rival, o Nacional, foi fundado em 1899 pelos estudantes locais ansiosos para defenderem a honra nacional. O milionário do chá escocês, Sir Thomas Lipton, doou a Taça Lipton em 1902, para ser disputada anualmente pela Argentina e Uruguai. De maneira semelhante, no Chile, o futebol foi introduzido pelos marinheiros britânicos no porto Valparaíso, onde o primeiro time foi formado em 1889. Seis anos depois, a Associação de Futebol Nacional foi formada por nove clubes fundamentalmente de origem britânica (Giullianoti, 2010: 23-25).

Esta citação de Giullianoti mostra como os contornos históricos da difusão do futebol fora da Inglaterra possuem denominadores comuns. Mesmo na América Latina a presença de ingleses do meio de transporte também foi grande. Há estas duas tendências da disseminação da prática, os estudantes e as linhas férreas.

A prática do futebol na cidade de São Paulo é um tanto complexa, mas desde a vinda de Miller muitas coisas ocorreram, como a criação do Germânia (1897), tendo Hans Nobling à frente. Em 1898 Augusto Shaw funda a Associação Atlética Mackenzie College. Rapidamente começam confrontos inter-regionais, ocorrendo a primeira tendência do futebol que é a polarização entre São Paulo e Rio de Janeiro. As duas cidades eram formadas por grande parte dos grupos sociais elitizados representados em clubes que praticavam o futebol. Por isso, já em 1901, no dia 19 de outubro, ocorreu o primeiro jogo de futebol entre paulistas e cariocas. Foram dois confrontos, ambos terminaram empatados em 1 a 1 e 2 a 2 (Figueiredo, 1918). Um pouco antes deste fato, ocorreu o primeiro jogo oficial de clubes paulistas em 1899, SPAC 0x0 Mackenzie. Após dois anos, em 1901 no dia 13 de dezembro, foi fundada a Liga Paulista de Futebol, a $1^{a}$ entidade a existir no Brasil destinada especialmente a esse esporte. São seus fundadores: São Paulo Athletic Club, Sport Club Germânia, Club Athletic Paulistano e Sport Club Internacional. A primeira partida oficial ocorreu no ano de 1902, Mackenzie 2x1 Germânia. E no ano de 1907 a seleção paulista venceu o $1^{\circ}$ campeonato brasileiro de futebol.

Voltando à discussão do processo de disseminação dos clubes de futebol no Estado de São Paulo, a cidade de Santos, como o local de transações econômicas por excelência, também participou do processo de constituição de clubes. No caso de Santos, a sua proximidade com o mar fortaleceu os clubes náuticos e de regatas, como: o Clube Regatas Santista - 1893; Internacional Regatas - 1898; Saldanha da Gama - 1903; São Vicente - 1905. Todos eles incorporaram o futebol, que desceu o planalto e atingiu o litoral. São Paulo e Santos possuem afinidades, demonstrando que eles eram locais de encontros das novidades e que construíam formas de identificação muito parecidas.

O futebol entre o amadorismo e o profissionalismo: disputas entre classes e diferentes apropriações simbólicas 
O surgimento das organizações esportivas vincula-se ao processo de identificação de grupos e pessoas, como a formação de grupos de imigrantes, bairros ou etnias. Mas o esporte surge também como potencializador da sociabilidade e construção de laços tão profundos quanto outros eventos sociais, como os jogos de azar, as formas de lazer gastronômico ou os encontros sociais. O esporte casa-se perfeitamente com os valores modernos e as pessoas incorporam novos símbolos desta atividade, ressignificando-o para além das regras de etiqueta e de formação do homem sem extingui-las, isto é, agregando valores do grupo à prática esportiva.

Os valores de limpeza e higiene, profilaxia e eugenia inserem-se em discussões relacionadas com a urbanização. Neste contexto, o futebol surge como uma nova forma de combater as ações nocivas da sociedade. Ao mesmo tempo em que incorpora o discurso higienista, o futebol adota sub-repticiamente a sociabilidade como forma primeira de se disseminar, pois os clubes nascem na cidade por vontade das pessoas, por desejo que são fortalecidos por doutrinas construídas por grupos e discursos médicos estabelecidos.

Os colégios e os clubes constituíam-se em espaços de sociabilidade, nos quais se representavam a "superioridade" da elite que procurava se fortalecer, num movimento endógeno, por meio da difusão de vínculos de solidariedade e do consequente afastamento dos demais setores sociais (Mills, 2005). Tais agentes tinham tanto os instrumentos para a prática quanto os saberes, regras, técnicas e terminologia inglesa. Tal processo de elitização do futebol foi longo. O Jornal dos Sports, na matéria de 06 de agosto de 1915, alertava que o "futebol é um esporte que só pode ser praticado por pessoas da mesma educação e cultivo, se formos obrigados a jogar com um operário a prática torna-se um suplício, um sacrifício, mas nunca uma diversão".

Nesta reportagem, o periódico busca fortalecer o caráter elitista do futebol que já havia ganhado uma popularização, havia a discussão de profissionalização do futebol e diversos interesses em jogo. Podemos abordar esta questão pelo processo de mercadorização da cultura, já que não existe vácuo quando as relações de mercado se estabelecem entre os novos valores culturais existentes. Noutro ponto podemos perceber que houve uma pluralidade na prática, o futebol perdeu a sua aura, no sentido benjaminiano (Benjamim, 1990), mas, ao mesmo tempo, popularizou-se.

No Brasil, Mazzoni (1950) faz uma abordagem calcada na identidade e miscigenação. Outros pontos de vista podem ser associados, como a incorporação do futebol na cultura popular. Para alguns autores, a prática do futebol faz parte de uma ritualização de festa. Podemos pensar também a discussão eliasiana (1982) de mimese, do caráter mimético das sociedades, do poder de imitação na formação da sociedade, pelo processo de teias e significados simbólicos.

Mas o importante neste processo de disseminação do futebol, em nossa opinião, é que o futebol e os valores esportivos estão vinculados com a urbanização e a ideia de evolução da sociedade que 
pairava no período, na busca de elementos para sair do atraso rural de época recente. A prática de um jogo cultivado pelos ingleses era o sinal que a sociedade paulista distanciava-se das "mulas cargueiras".

Quando se ampliam as formas de encontro, novas formas de sociabilidade vão se constituindo, lembrando um pouco a discussão durkheimniana de densidade material e densidade moral, para mostrar que há uma transformação das cidades quando diversas pessoas se encontram e várias características culturais se consolidam (Almeida \& Gutierrez, 2010).

Enquanto ocorria a popularização do futebol, a elite ampliava seus espaços de lazer, frequentando o Jockey Club, à rua XV de novembro, que tinha anexo a ele um clube de diversões com bilhares, jogos lícitos e salas de leitura e palestras, o hipódromo na Mooca, e o velódromo, à Rua da Consolação, localizado em meio a um vasto Jardim, onde se realizavam corridas de bicicletas (Rago, 2004). Posteriormente, o velódromo foi reformado para a prática do futebol e recebia os jogos do campeonato paulista. Os esportes tiveram muitos incentivos e elogios. Futebol, natação, remo, tênis e ciclismo eram promovidos nos clubes privados que cresciam na cidade como Clube Atlético Paulistano, Associação Atlética São Paulo, o Espéria e o Palestra Itália.

\begin{abstract}
Mesmo nas práticas esportivas revelava-se uma forte segregação das classes sociais, para além de suas dimensões racistas e sexistas. Alguns esportes como o tênis e a equitação, eram praticados majoritariamente pelos homens brancos da elite, em seus clubes privados, o tênis clube e o hipódromo. A importação dos sports e da ideia de clubs privados da Inglaterra foi acompanhada dos valores aristocráticos da origem, resultando, no Brasil, na violenta exclusão de trabalhadores braçais, dos negros, dos homossexuais e dos pobres dos códigos definidores dos que podiam competir. Assim, da regulamentação do remo, constavam, por exemplo, artigos que impediam a participação dos criados de servir de hotéis, cafés, bares, confeitarias e bilhares, condutores de veículos; os de profissão manual que não exija esforço mental, e os operários, entre outros (Rago, 2004: 393).
\end{abstract}

Mesmo com estas proibições nos clubes de elite, a prática livre ocorria em espaços outros, como nas margens do Rio Tietê e nas suas várzeas. Isto é, havia a restrição de jogar nestes espaços particulares, mas nas ruas, nos terrenos baldios, a prática começa a aparecer de forma cada vez mais frequente. Clubes desconhecidos, como os clubes de bairros - Pinheiros, Brás, Bom Retiro concentram seus sócios que praticam o futebol de uma forma informal. "Modalidades como a natação e o futebol, ganhavam rapidamente adeptos por toda a cidade, tanto praticadas em inúmeros clubes que surgiam por toda a parte, quanto nos campos, várzeas, rios, tomados pela população, incluindo-se a negra” (Rago, 2004: 401).

A cidade de São Paulo na década de 1910 e 1920 vivia uma dicotomia. Sua cartografia dual coloca, de um lado, a cidade da ordem, da moral, das boas famílias do cosmopolitismo exemplar dado pelos ricos e, do outro lado, a cidade às avessas, a desordem, a amoralidade e a vadiagem. A cada uma 
dessas cidades correspondia um espaço específico em um tempo determinado. De um lado, a cidade legal, onde tempos e espaços não se misturavam: o espaço do trabalho estava separado do tempo da casa, o tempo de lazer era distinto do espaço da rua. De outro lado, estavam os bairros populares onde trabalho, moradia e lazer estavam sobrepostos no tempo e espaço. Nestes bairros populares, a legalidade urbana que configurava a boa cidade era continuamente subvertida e ressignificada. A distância material e simbólica entre uma cidade e a outra era abissal (Paoli \& Duarte, 2004: 55-56):

São Paulo popular. Deste lado do Tamanduateí, totalmente desconhecidos dos salões cultos e sofisticados da cidade. Nos cortiços do Brás - nas vielas do Bexiga, nos botequins da Barra Funda, o teatro, o cinema, a ópera são atividades eminentemente populares, sobretudo o primeiro encenado nas ligas operárias, na sociedade de auxilio mútuo, nas ruas, nos clubes esportivos, nos centros de cultura social anarcosindicalistas. Uma cultura que, aparentemente, começa sob influência da parcela politizada de imigrantes italianos, mas que, a medida que se entende como cultura de classe, pouco a pouco incorpora a inspiração vinda os imigrantes espanhóis, portugueses, húngaros, russos, lituanos, árabes e outros, bem como uma cultura negra nos bairros periféricos.

O São Paulo popular tinha uma dinâmica própria, criava seus espaços de sociabilidade como os clubes esportivos e a rua. Espaços de lazer e de encontros onde se construíam formas de intersubjetividades, valorizando o próprio bairro, e criando uma identidade distinta dos locais frequentados pelos senhores do Clube Paulistano.

Desta população que frequentava o centro e tinha seus espaços cerceados pela polícia, surgiam associações de carnaval e clubes de futebol. "O grupo carnavalesco Barra Funda fundado em 1914, o Campos Elíseos em 1917 e a Vai-Vai na década de 20. No futebol, os mais conhecidos eram a Associação Athletica São Geraldo e Clube Cravos Vermelhos, ambos fundados na década de 1910" (Paoli \& Duarte, 2004, p.57-58).

Havia também os clubes de futebol que representavam grupos étnicos, como o Luva Preta (1904) e o Cosmos (1908), que era frequentado pela população negra. Isso ilustra como analisar os clubes de futebol é uma tarefa complexa, em que o importante é destacar que o clube de futebol não é algo apenas ligado à elite, e sim um espaço de sociabilidade que tinha diversas características, não somente econômica, mas de identidades distintas, como país, etnia, imigrante, classe, bairro e afinidade eletiva (Borges \& Cohen, 2004).

O futebol ganhou grande notoriedade no Estado de São Paulo, a partir da criação de uma prática de ampliação da sociabilidade. Com isso, teve grande influência na consolidação do Estado como ponto de encontro e inseriu sua capital no cenário internacional das grandes cidades do mundo. O futebol não custou muito para conquistar a população, de alto a baixo, nas várzeas, nos terrenos baldios próximos às fábricas, nos pátios dos colégios, nos clubes, ou nas arquibancadas do Parque 
Antártica. Tota (2004) afirma que o futebol, já nos anos 30, perdeu seu caráter elitista e passou a ser a paixão de um povo. Nicolau Tuma, precursor da locução futebolística, já dizia da nova paixão dos paulistas. Atento às expectativas, sentiu que os ouvintes esperavam mais do que as poucas narrações. Ele começa a criar uma imagem do jogo na fala pelos rádios, este foi o grande meio de comunicação do futebol.

Em um texto que discute hipóteses sobre o processo de popularização do futebol em São Paulo (Streapco \& Rubio, 2009), aponta-se a dinamização da sociedade e os registros materiais da cidade colonial. A cidade de São Paulo foi reconstruída e nesta reconstrução os vestígios anteriores à República apagaram um pouco da memória a evolução do futebol em São Paulo.

A Festa da Penha, a mais popular festa de São Paulo no final do século XIX, atraía inúmeras pessoas não apenas pela religião, mas por outras modalidades lúdicas e de lazer de caráter laico. Pelota, ciclismo, natação, basquete, pedestrianismo e todas as modalidades esportivas começavam a despertar a atenção da população que aos poucos passava a se dividir entre os festejos religiosos e as práticas laicas. Em 1897 o jornal "A Platéia" anunciava que todos que ali vão, uns por devoção, outros simplesmente por espírito de curiosidade, encontram ali os melhores atrativos, a começar pelos conhecidos cavalinhos de pau, e a terminar no Coliseu Festa Alegre, que tem feito as delícias dos que ali vão, atenta a concorrência de amadores, não só do esporte de pelota como do ciclismo (Streapco \& Rubio, 2006: 6).

Em 1896, o jardim central do Velódromo de São Paulo foi transformado em campo de futebol dentro das normas internacionais, através do nivelamento realizado pelo construtor Valério José, autorizado pela Câmara Municipal. Entre 1896 e 1917 (ano de sua demolição), o velódromo foi a principal praça esportiva de São Paulo dedicada ao futebol, local onde se organizou o chamado futebol oficial da cidade, através da fundação da Liga Paulista de Futebol, em que os times e jovens da elite disputavam torneios e amistosos interestaduais.

A Chácara da Floresta se transformou no principal espaço esportivo da cidade após a demolição do Velódromo, assim permanecendo até a inauguração do Estádio Municipal de São Paulo, o Pacaembu em 1940. O Parque Antarctica foi construído no início do século XX pela Cia. Antarctica Paulista para ser utilizado como uma área de lazer para a população, sendo aproveitado por diversas equipes neste período. Posteriormente, o Parque Antarctica foi comprado pela Sociedade Esportiva Palestra Itália.

\section{O futebol e a cultura popular: manifestação corporal brasileira ou inglesa?}

Uma vertente que discute a apropriação do futebol pelo brasileiro também parte de algumas discussões de Mauss (1980) sobre técnica corporal representativa de uma identidade cultural específica. Se, hoje, podemos falar em mimetismo no caso do futebol em nossa sociedade (Franco Jr., 2007), este 
ocorreu porque a população brasileira dominava determinadas técnicas do corpo que lhe permitiram se servir do futebol como instrumento de lazer, de atividade social ou identitária. A técnica do corpo pode ser entendida como as maneiras pelas quais os homens, de sociedade a sociedade, de uma forma tradicional, sabem servir-se de seu corpo. O futebol tornou possível a sublimação de vários elementos de nossa formação social e de cultura. Nas palavras de Rodrigues (2003), elementos da cultura nacional, consolidadas pela abertura ao negro e mulato, permitiu uma síntese com o jogo dos pés. O cadinho destes elementos são uma das formas de ver a relação futebol e Brasil.

A capoeiragem e o samba, por exemplo, estão presentes de tal forma no estilo brasileiro de jogar futebol que de um jogador um tanto álgido como Domingos, admirável em seu modo de jogar, mas quase sem floreios - os floreios barrocos são do gosto brasileiro - um crítico da argúcia do Mário Filho pode dizer que ele está mais para o nosso futebol como Machado de Assis está para a nossa literatura, isto é, na situação de uma espécie de inglês desgarrado entre tropicais... Com esses resíduos é que o futebol brasileiro afastou-se do bem ordenado original britânico para tornar-se a dança cheia de surpresas irracionais e de variações dionisíacas que é. A dança dançada baianamente por um Leônidas; e por um Domingos, com uma impassibilidade que talvez acuse sugestões ou influências ameríndias sobre sua personalidade ou sua formação. Mas de qualquer modo, dança (Rodrigues, 2003: 25).

Talvez o maior exemplo desta mistura, segundo Nelson Rodrigues, seja o mulato Friedenreich, filho reconhecido de alemão com mãe negra, que se tornou herói ao marcar o gol da vitória brasileira no Campeonato Sul-Americano de 1919. Contudo, o feito torna-se secundário. Mário Filho diz que Friedenreich não se tornara herói simplesmente por ter marcado o gol da vitória, mas por ser mulato, à imagem e semelhança de seu povo. Em uma de suas afirmativas contundentes, Mário Filho afirma que o povo prefere construir um herói à sua imagem do que "um branco de olhos azuis".

Mais do que representar uma cidade ou um Estado, o futebol constrói uma identidade. Esta identidade relaciona-se com a democratização do futebol, com a participação de segmentos outros que não o elitizado ${ }^{1}$. Dá-se pela incorporação do rádio para ouvir as partidas e, ao mesmo tempo, utilizar os espaços públicos para jogar bola.

O futebol adquiriu foros de nacionalidade. Para um país tão heterogêneo e fragmentado por interesses regionais, a construção da nacionalidade brasileira teve no futebol um dos seus principais

\footnotetext{
${ }^{1} \mathrm{O}$ processo de disseminação do futebol no Brasil não foi consensual, existindo uma defesa ao amadorismo, ao cavalheirismo que tinha claramente um corte social, trabalhadores e negros não poderiam praticar este esporte em locais oficiais, ou em clubes de elite. Por exemplo, em Minas Gerais, em 1904, foi publicado um artigo sobre quem deveria jogar o sport, o esportista é vinculado a elegância e nobreza. "Não são considerados os que exercem profissões ou emprego que não esteja de acordo com o nível moral e social em que deve ser mantido o sport". Segundo a Gazeta de Notícias, de 18 de maio de 1907, o Bangu Athletico Club proibiu o registro de pessoas de cor. Um amador era uma pessoa que não fazia trabalho braçal, jogos de azar; seriam proibidos de jogar aqueles que não soubessem ler e escrever; aqueles que não tinham profissão ou aqueles que exerciam trabalhos subalternos.
} 
alicerces. Os embates com times estrangeiros e as primeiras partidas da seleção brasileira alimentaram certa dose de patriotismo e de sentimento de unidade. Em 1914, um combinado Rio - São Paulo derrotou a equipe inglesa do Exeter City por 2 a 0 nas Laranjeiras - estádio do Fluminense (RJ), considerado o primeiro jogo da seleção. Ainda neste ano, a seleção conquistou a Copa Roca na Argentina, mostrando que o sentimento de pertencimento do futebol com os brasileiros foi anterior às vitórias nos mundiais. Há uma identificação, difícil de encontrar a gênese, entre esta modalidade e o brasileiro.

A partir do início dos anos de 1930, houve um crescimento com a cobertura jornalística de Mário Filho e as locuções no rádio. A população passou a se vincular mais fortemente a determinados clubes, dentro e fora dos estádios. Segundo DaMatta (1982: 82), o futebol "proporciona uma experiência exemplar de legitimidade e de acatamento de leis", engendrando um espaço primordialmente democrático. Outra abordagem é pensá-lo como metáfora de nação. Machado (200: 12) demonstrou como gradualmente o futebol se tornou um dos instrumentos brasileiros de pensar e de, sobretudo, classificar o mundo. Para ele "a nação brasileira não é apenas metaforizada no futebol, ela passa a 'existir' como algo concreto e palpável através das imagens constituídas a partir desse esporte". Entender o futebol é entender uma dimensão importante da nação brasileira; é entender nossa cultura.

$\mathrm{Na}$ sociedade paulista, a identidade do futebol começa com o próprio jogo, mas com o tempo adota contornos com os bairros e os clubes que nascem por meio de diferentes cortes sociais. Podemos falar de clubes de imigrantes como Sírio, São Paulo Athletic Club, Germânia, Palestra; outros com corte de classe bem definido como o Paulistano, ou pequenos clubes de bairro do Bom Retiro, Ipiranga, Mooca. Não existe uma única forma de classificação dos clubes de futebol. Talvez a mais marcante seja a separação dos clubes que participam do futebol oficial e todos aqueles outros, que tem características muito singulares.

O futebol agrega um conjunto de linguagens para discorrer sobre o mundo, este mundo bem conhecido por brasileiros dos mais variados segmentos sociais. Desde a década de 1920, consolidandose em 1930, o futebol se firma como o esporte mais popular do Brasil. Os clubes elitistas que tinham times de futebol, em um processo cheio de contradições e distensões, começam a profissionalizar seus quadros. Alguns clubes saíram do circuito por não concordar com esta política e novos clubes iniciaram este processo, dando maior oportunidade aos jogadores negros e de segmentos sociais inferiores.

Para DaMatta, o futebol transforma a vida social em um espetáculo de derrotas e vitórias. O futebol e a arquibancada são territórios de um local único e de intensos conflitos. Branco (2010) traz alguns relatos orais de pessoas que participaram do processo de desenvolvimento do futebol em São Paulo. Mesmo percebendo que há uma construção e valorização do passado como belo, as falas 
constroem os espaços do jogar, e como o futebol vai se difundindo nas regiões, independentemente do poder público, ou mesmo, dos grandes times que disputavam o campeonato paulista.

Hoje as pessoas não jogam nem dez por cento daquilo que jogavam naquele tempo [década de 1930], por falta de campo, de lugar. Não tem onde jogar. Em cada bairro se fazia um campeonato, juntavam dez ou vinte clubes. Ali era uma coisa! O jogo da várzea era o que atraía a maior parte do público. De grande havia o campo da Ponte Pequena, do Corinthians velho, e o campo do Sírio. Depois veio o Parque Antártica e o Parque São Jorge. A gente dizia: "Em que parque vamos jogar?" Não tinha ainda estádio, era campo livre, ninguém pagava pra ver. O Pacaembu veio mais tarde, acho que em 38 ou 40. Aí começou a massa, antes o pessoal estava espalhado nas várzeas e nos bairros jogando mesmo (Branco, 2010: 8).

Segundo o autor, somente com o envolvimento da população é que foram pensados e construídos estádios para grande público. Novamente, parece-nos que o futebol desenvolve-se pela sua identificação com a nação brasileira, nos dizeres de DaMatta, e o governo foi a reboque deste processo. Surgia, no final da década, o fenômeno das grandes massas em grandes estádios. O Pacaembu e o São Januário seriam utilizados inúmeras vezes pelo governo, para promover festas cívicas, equiparáveis às festas coletivas associadas ao futebol':

A paixão começou a correr solta. Tanto, que passava agora, a ser uma preocupação para o Novo Estado, já que começava a transbordar do período reservado ao ócio e passava a ocupar também o venerado e "imprescindível" período de trabalho, contrariando desta forma, "os interesses nacionais", na visão do novo governo (Branco, 2010: 13).

Nas metrópoles surgidas pela imigração, como São Paulo, ou cidades que se desenvolveram como Campinas, Ribeirão Preto, Franca, Sorocaba, poucos tinham raízes ou tradições, grande parte da população vinha de diferentes partes do mundo ou dos rincões do Brasil. Na busca de novos traços de identidade e de solidariedade coletiva, de novas bases emocionais de coesão que substituíssem as comunidades originais, a identidade do time, do clube e do grupo foram primordiais. A paixão futebolística serviu de elemento agregador da sociedade e dos novos imigrantes e migrantes das cidades paulistas.

Nestas discussões sobre o processo de popularização do futebol, cabe sempre lembrar que o Brasil já tinha o futebol incorporado à sua marca cultural, antes mesmo de vencer o primeiro campeonato mundial de seleções, como podemos recordar a Campanha do Selo em 1938.

2 O artigo: "A esportivização da sociedade brasileira" (ALMEIDA, 2011) trata destas questões, de como a sociedade foi incorporando termos relacionados ao futebol. 
A Campanha do Selo, a tão bem inspirada iniciativa, teve um sucesso invulgar, ao se iniciar há dias, no Rio, está quase esgotada a emissão de 100 mil selos. Com essa campanha os afeiçoados podem se interessar diretamente pela viagem da nossa seleção, pois adquirindo um selo o "torcedor" faz sua fezinha de ir também à "Taça do Mundo". Os que adquirirem o "selo cebedense" não só auxiliarão patrioticamente o comparecimento do Brasil na III "Taça do Mundo" como se tornarão, igualmente, candidatos a um lugar na delegação por...500 réis. Assim, enquanto os "fans" gastarão uma quantia tão modesta, a CBD, para cada emissão, arrecadará 50 contos, uma quantia que muito contribuirá para a nossa seleção viajar com maior comodidade, para melhor se hospedar na França, etc. E tudo isso importa na melhor disposição dos nossos "azes" (Gazeta de Notícias, 1938: 8).

Segundo Negreiros (2003: 134) adquirir tal característica não era somente a esperança própria de se ir à Europa assistir o Campeonato Mundial, como também um ato patriótico para melhor servir o nosso ideal comum de vermos o Brasil atingir o posto supremo no futebol internacional, que seria a conquista da "Taça do Mundo"!

Colocando a sua filha como a madrinha da seleção de 1938, o presidente Vargas demonstra claramente a importância dada ao futebol no Brasil, já neste período. No seu diário escreveu ele: “a perda do team brasileiro para os italianos causou grande decepção e tristeza no espírito público, como se tratasse de uma desgraça nacional".

A Copa do Mundo de 1938 será lembrada pela sua transmissão via rádio. Com a divulgação para todos os lugares, a seleção começa a ter uma relação mais orgânica com a Copa do Mundo; neste sentido inicia-se um processo de sentimento de relação entre a seleção e o Brasil.

Pela primeira vez as partidas do selecionado nacional na Copa do Mundo seriam transmitidas diretamente para o Brasil via rádio. Assim como ocorrera no sulamericano de 1936-7, disputado em Buenos Aires, a Rádio Club do Brasil (PRA-3), emissora do Rio de Janeiro - em parceria com o Cassino da Urca, o Jornal dos Sports e O Globo - adquiriu (por uma alta quantia de cerca de 100 contos de réis por partida) os direitos de transmissão dos jogos do escrete brasileiro em tempo real para os principais Estados do país. A irradiação seria redistribuída, como forma de divisão de gastos, por cerca de 45 emissoras que compunham a Rede Nacional, através do programa "Hora do Brasil" (Jornal Dos Sports, 1938).

Com o avanço dos rádios e dos jornais especializados, a Copa de 1938 será lembrada pelos grandes cronistas, que tinham uma importância especial no período, ao construir simbolicamente o jogo para o qual se voltavam os olhos de todos os brasileiros. Fortalecem-se assim os laços e se cria toda uma linguagem característica do futebol, que será reproduzida, reinventada e festejada durante todo este período.

Os nossos passes, os nossos pitu's, os nossos despistamentos, os nossos floreios com a bola, o alguma coisa de dança e de capoeiragem que marca o estilo brasileiro de 
jogar foot-ball, que arredonda e adoça o jogo inventado pelos ingleses e por eles e por outros europeus jogados tão angulosamente, tudo isso parece exprimir de modo interessantíssimo para os psicólogos e os sociólogos o mulatismo flamboyant e ao mesmo tempo malandro que está hoje em tudo que é afirmação verdadeira do Brasil. Acaba de se definir de maneira inconfundível um estilo brasileiro de football; inimigo do formalismo apolíneo, e amigo das variações e dionisíaco a seu jeito - o grande jeitão mulato. Deliciando-se em manhas moleronas mineiras a que se sucedem surpresas de agilidade. A arte do songa-monga. Uma arte que não abandona nunca à disciplina do método científico, mas procura reunir ao suficiente de combinação de esforços e de efeitos em massa a liberdade para a variação, para o floreio, para o improviso (Jornal Dos Sports, 1938).

Neste momento histórico, principalmente a imprensa brasileira passou a associar o futebol ao imponderado, ao improviso, e utilizou-se disso como forma de simboliza-lo como um importante traço cultural do jeito brasileiro de viver. Os cronistas auxiliaram neste processo de construção da identidade. Estas vozes criaram um universo no qual foi possível identificar o futebol com a cultura nacional. Ao criticar a forma de jogar dos europeus frente à nossa, mostra-se que este conflito é mais uma maneira de valorizar as características brasileiras, mais um jeito de reforçar a identidade, construindo os motivos do porque devemos torcer pelo Brasil, do porque o futebol é o Brasil. Os jogadores são o Brasil.

Faz-se importante destacar que tal linguagem e estereótipo construído caracterizam-se como uma forma criada para aproximar o futebol de uma ideologia de identificação cultural brasileira. Deste modo, sustenta-se em certa idealização desta forma brasileira de ser e jogar, que não necessariamente retratou a realidade objetiva do início do século XX e também não o faz nos dias de hoje.

São conhecidas as palavras de Nelson Rodrigues, em uma matéria em junho de 1966, quando afirmava que as histórias de um país e de um povo poderiam ser escritas por meio do futebol. Neste contexto, já havia neste período uma discussão sobre o papel social do futebol no Brasil. Qual era sua relevância para compreendermos a cultura brasileira e que significado, quais símbolos são valorizados nesta cultura.

Havia também toda uma discussão sobre o papel do Brasil no mundo, quem somos nós e do que somos capazes. A célebre discussão sobre o complexo de vira-latas dá margem a reflexões sobre o que queríamos ser e para onde o Brasil caminhava. Nas palavras de Nelson Rodrigues:

Por complexo de vira-latas entendo eu a inferioridade em que o brasileiro se coloca, voluntariamente, em face do resto do mundo. Isto em todos os setores e, sobretudo, no futebol. Dizer que nós nos julgamos os maiores é uma cínica inverdade... já na citada vergonha de 50 éramos superiores aos adversários. Além disso, levávamos a vantagem do empate. Pois bem: perdemos de maneira mais abjeta. Por um motivo muito simples: - porque Abdulio nos tratou a ponta pés como se vira-lata fôssemos. [...] Eu vos digo: - o problema do escrete não é mais futebol, nem de técnica, nem de tática. Absolutamente. É um problema de fé em si mesmo. O brasileiro precisa se convencer de que não é um vira-lata e que tem futebol para dar e vender lá na Suécia (Manchete esportiva, 1958). 
À parte das discussões sobre a Copa de 1958 na Suécia, em que o Brasil venceu na Europa, o importante neste trecho é entendê-lo como elemento de uma narrativa do que é ser brasileiro e da importância do futebol na cultura nacional. O selecionado, as pessoas passivas no Maracanã no dia 16 de julho de 1950, representam um brasileiro vira-lata, alguém que não defende sua bandeira.

\begin{abstract}
Até mesmo a liberdade para a ostentação ou para a exibição de talento individual num jogo de que os europeus têm procurado eliminar quase todo o floreio artístico, quase toda a variação individual, quase toda a espontaneidade pessoal para acentuar a beleza dos efeitos geométricos e a pureza de técnica científica. Sente-se nesse contraste o choque do mulatismo brasileiro com o arianismo europeu. $\mathrm{O}$ contraste pode ser alongado: o nosso foot-ball mulato, com seus floreios artísticos, cuja eficiência menos na defesa que no ataque - ficou demonstrada brilhantemente nos encontros deste ano com os poloneses e os tchecoslovacos é uma expressão de nossa formação social democrática como nenhuma. Rebelde a excessos de ordenação interna e externa; há excessos de uniformização de geometrização, de standardização; há totalitarismos que façam desaparecer a variação individual ou espontaneidade pessoal. No foot-ball como na política, o mulatismo brasileiro se faz marcar por um gosto de flexão, de surpresa, de floreios que lembra passos de dança e de capoeiragem. Mas, sobretudo de dança. Dança dionisíaca. Dança que permita o improviso, a diversidade, a espontaneidade individual. Dança lírica. Enquanto o foot-ball europeu é uma expressão apolínea de método científico e de sport socialista em que a pessoa humana resulta mecanizada e subordinada ao todo - o brasileiro é uma forma de dança, em que a pessoa humana se destaca e brilha.
\end{abstract}

A força da identidade no futebol reforça os signos brasileiros que habitavam o universo dos cronistas, muitos deles influenciados pelas pesquisas de Gilberto Freyre. A impressão e o ideário divulgados eram de que o mulato brasileiro "deseuropeizou" o football dando-lhe curvas, arredondados e graças de dança. Foi precisamente o que sentiu o cronista europeu que chamou aos jogadores brasileiros de bailarinos da bola. O estilo mulato, afro-brasileiro, de football é uma forma de dança dionisíaca, como diria DaMatta (1982).

Segundo Negreiros (1998) desde o início dos anos de 1920, os estádios da cidade de São Paulo já não comportavam todos os torcedores que desejavam assistir a uma importante partida de futebol. Em 1936, o esporte era valorizado e construir um estádio, poliesportivo e com pista de atletismo, favorecia os ideais do período. Com Francisco Prestes Maia no Estado Novo, o estádio do Pacaembu começou a ser construído de maneira mais eficiente, com a intervenção no espaço urbano o estádio alterou a região. Buscou-se construir o que a nova história iria denominar de monumento. Em abril de 1940, o Estádio Municipal do Pacaembu ficou pronto e houve inúmeros festejos. O estádio foi pensado para desenvolver o esporte. 
A inauguração oficial do Estádio Municipal de São Paulo, que se realizou na tarde morna e luminosa de ontem, constituiu um espetáculo de inédita beleza e sadio entusiasmo, enchendo de alegria e legítimo orgulho os olhos e o espírito de toda a multidão ali presente às cerimônias de abertura da majestosa praça que lhe dá a primazia na América do Sul, em mais esse setor (Negreiros, 1998: 325).

Mazzoni considerava o surgimento do Estádio do Pacaembu como um importante divisor de águas. É possível falar do futebol em São Paulo antes do Pacaembu e com ele. Para a crônica esportiva, o Pacaembu fez crescer ainda mais a popularidade do esporte bretão em São Paulo:

[...] A 'época de ouro Pacaembu', como é sabido, nasceu em 1940, com a inauguração do Estádio Municipal e desde aí cada ano que passa houve um novo recorde de renda. Desde 1943 vem se perguntando se a 'época Pacaembu' atingiu o seu máximo pra daí não provocar mais recorde de renda... mas vimos que se em 43 as rendas de 1940, $41 \mathrm{e}$ 42 ficaram para trás, e, 44 aconteceu o mesmo em relação a 43 [...] (MAZZONI, 1945).

As palavras do presidente do Estado Novo na abertura do Estádio do Pacaembu mostram a valorização da cultura física e o futebol, levando a reboque as outras modalidades. O governo se apropriou de algo que veio da massa, para valorizar os seus objetivos, que era o trabalho, a disciplina e o físico. Para esclarecer esta colagem do futebol, nação e governo tornou-se emblemático o discurso de Vargas na inauguração do Pacaembu em 28 de abril de 1940.

Este monumento consagrado à cultura física da mocidade, em pleno coração da capital paulista, é motivo de justo orgulho para todos os brasileiros e autoriza aplaudir merecidamente a administração que o construiu. As linha sóbrias e belas da sua imponente massa de cimento e ferro, não valem, apenas, como expressão arquitetônica, valem como uma afirmação da nossa capacidade e do esforço criador do novo regime na execução do seu programa de realizações.

É ainda, e, sobretudo, este monumental campo de jogos desportivos uma obra de sadio patriotismo, pela sua finalidade de cultura física e educação cívica.

Agora mesmo assistimos ao desfile de dez mil atletas, em cujas evoluções, havia a precisão e a disciplina, conjugadas no simbolismo das cores nacionais. Diante dessa demonstração da mocidade forte e vibrante, índice eugênico da raça, - mocidade em que confio e que me faz orgulhoso de ser brasileiro - quero dizer-vos: Povo de S. Paulo!...Compreendestes perfeitamente que o Estádio do Pacaembu é obra vossa e para ela contribuístes com o vosso esforço e a vossa solidariedade. E compreendestes ainda que este monumento é como um marco da grandeza de São Paulo a serviço do Brasil.

Declaro, assim, inaugurado o Estádio do Pacaembu.

Ao mesmo tempo, é preciso destacar que o governo não conseguiu controlar o corpo e a alma das pessoas pelo esporte. O futebol e as associações de futebol foram espaços de resistência ao regime. Todo este discurso do futebol como utilização e estratégia do Estado deve ser relativizado, pois há 
inúmeras pesquisas que apontam o futebol como local de distensões das políticas varguistas, mostrando como é complexo este fenômeno.

O que o agente do Dops não percebeu, é que as relações entre os operários davam-se nas organizações de bairros, os clubes de futebol e as associações culturais de várias comunidades étnicas, não apenas porque as pessoas participavam de ambas, mas, principalmente, porque as experiências de sociabilidade nessas associações contribuíram para a organização das comissões de fábrica (Paoli \& Duarte, 2004: 68).

Em entrevista realizada pelas pesquisadoras Paoli e Duarte em 28 de agosto de 1999, João Louzada, que era da Comissão de Fábrica da Matarazzo, conta como foi o processo de entrada nesta Comissão.

Progresso Paulista F. C. o presidente era o Sr. Vicente, que era mestre no Matarazzo, no Belenzinho, o técnico era o Sr. Dante, que era mestre numa secção da Cia. Gás, lá na rua do Gasômentro. Eu fui jogador, fundador e depois presidente. No último jogo perdemos do Flor do Ipiranga 4x2. No campo da Siqueira Bueno. O pessoal depois me chamou para fazer parte da comissão de fábrica (Paoli \& Duarte, 2004: 87).

Podemos interpretar estes dados mostrando que a concentração e a proximidade com as indústrias parecem ter contribuído decisivamente para a difusão da experiência organizativa das comissões internas que se disseminaram, bem como para sua relativa estabilidade e duração. Entretanto, se as práticas organizativas passavam de fábrica a fábrica, de um local de trabalho a outro, é preciso considerar que o sucesso e a longevidade das comissões de fábrica devem um tributo, nem sempre visível e reconhecido, às organizações do bairro, em especial aos clubes de futebol e às organizações festivas em geral. O clube de futebol era mais que simplesmente o jogo. Ele possui uma dimensão política e social, às vezes esquecidas, que nos leva a relativizar as afirmações deterministas que apontam o futebol como ópio do povo.

\section{Considerações finais}

Neste ensaio, discutimos alguns aspectos do futebol, a partir de um olhar sistêmico da sociedade. Apontamos autores das ciências sociais que interpretaram a relação sistêmica entre futebol, nação e brasilidade, a partir dos seguintes temas geradores: o corpo, a ginga e a reinterpretação cultural de um jogo praticado por ingleses em São Paulo, para uma ressignificação brasileira de como jogar e valorizar o futebol como um patrimônio cultural. As discussões entre territórios e as identidades do futebol no Estado de São Paulo, apontou como foram constituídos espaços e a sua transformação, de um jogo praticado às margens do Rio Tietê, até a construção do monumento do Estádio Municipal do Pacaembu. 
Em termos bem simples, o futebol nos limites deste artigo é um fenômeno sociocultural que representa a principal manifestação esportiva no Brasil. Ele participa da configuração cultural como forma de melhor descrever a sociedade brasileira, visto que é um dos poucos fenômenos sociais que sintetiza a nossa nacionalidade de grande abrangência territorial e diversidade cultural.

\section{Referências Bibliográficas}

Almeida, M. \& Gutierrez, G. (2011) Lazer no Brasil. São Paulo: Phorte.

Almeida, M.; Gutierrez, G. \& Ferreira, R. (2010) Futebol e ferrovia: a história de um trem da industrialização que parte para o noroeste paulista. Revista Brasileira de Educação Física e Esporte, São Paulo, v. 24, n. 2, pp. 249-258.

Benjamim, W. (1985) Obras escolhidas. v. 1. Magia e técnica, arte e política. São Paulo: Brasilense.

Borges, V. P. \& Cohen, I. (2004) A cidade como palco: os movimentos armados de 1924, 1930 e 1932. In: Porta, P. (Org.). História da Cidade De São Paulo. A cidade na primeira metade do século XX 1890- 1954, v. 3. São Paulo: Paz e Terra, pp. 291-339.

Branco, C. (2010) O futebol e a música popular brasileira (1915-1990). Recorde: Revista de História do Esporte. Rio de Janeiro, v. 3, n. 1, pp. 1-15.

DaMatta, R. (1982) Esporte na sociedade: um ensaio sobre o futebol brasileiro. In: DaMatta, R. (Org.) Universo do Futebol. Rio de Janeiro: Pinakotheke. pp. 19-42.

Dunning, E. \& Curry, G. (2006) Escolas Públicas, Rivalidade Social e o Desenvolvimento do Futebol. In: Gebara, A. \& Pilatti, L. A. (orgs.). Ensaios Sobre História e Sociologia nos Esportes. Jundiaí (SP): Fontoura.

Elias, N. (1982) Introdução à sociologia. São Paulo: Martins Fontes.

Elias, N. \& Dunning, E. (1992) A busca da excitação. Lisboa: Difel.

Figueiredo, A. (1918) História do foot-ball em São Paulo. Seção obras do Estado de São Paulo.

Franco Jr., H. (2007) A dança dos deuses: futebol, sociedade, cultura. São Paulo: Cia. Das Letras.

Gazeta de Notícias, 6.04.1938.

Giulianotti, R. (2010) Sociologia do futebol: dimensões históricas e socioculturais do esporte das multidões. São Paulo: Nova Alexandria.

Jornal dos Sports, 28.03.1938.

Jornal dos Sports, 10.04.1938. 
Manchete Esportiva, 31.05.1958.

Mauss, M. (1974) As técnicas corporais. In: Sociologia e antropologia. v. 2. São Paulo: EPU, pp. 209233.

Mazzoni, T. (1945) Mais alto ainda? A Gazeta, 06.04.1945, p. 10.

Mazzoni, T. (1950) História do futebol no Brasil - 1894-1950. São Paulo: Edições Leia.

Negreiros. P. (1998) A nação entra em campo: futebol nos anos 30 e 40. Tese de doutorado em História. São Paulo: PUC.

Negreiros. P. (2003) Futebol nos anos 1930 e 1940: construindo a identidade nacional. História: Questões \& Debates, Curitiba, n. 39, pp. 121-151.

Nogueira, C. (2006) Futebol Brasil Memória: de Oscar Cox a Leônidas da Silva (1897-1937). Rio de Janeiro: Editora Senac Rio.

Paoli, M. C. \& Duarte, A. (2004) São Paulo no plural: espaço público e redes de sociabilidade. In: Porta, P. (Org.). História da cidade de São Paulo. A cidade na primeira metade do século XX - 1890-1954. v. 3. São Paulo: Paz e terra, pp. 53-99.

Rodrigues Filho, N. (1964) O negro no futebol brasileiro. 2. ed. Rio de Janeiro: Civilização Brasileira.

Rago, M. (2004) A Invenção do cotidiano na metrópole: sociabilidade e lazer em São Paulo, 1900-1950. In: Porta, P. (Org.). História da cidade de São Paulo. A cidade na primeira metade do século XX 1890-1954. v. 3. São Paulo: Paz e terra, pp. 387-435.

Rosenfeld, A. (1973) O futebol no Brasil. Revista Argumento, Rio de Janeiro, n. 4, pp. 62-63.

Streapco, J. \& Rubio, K. (2009) Hipóteses para a popularização do futebol em São Paulo (1894-1920). Recorde: Revista de História do Esporte. v. 2, n. 1.

Suzigan, W. (1986) A industrialização brasileira: origem e desenvolvimento. São Paulo, Editora Brasiliense.

Tota, A. (2004) Radio e modernidade em São Paulo (1924-1954). In: Porta, P. (Org.). História da cidade de São Paulo. A cidade na primeira metade do século XX - 1890-1954. v. 3. São Paulo: Paz e terra, pp. 487-515. 